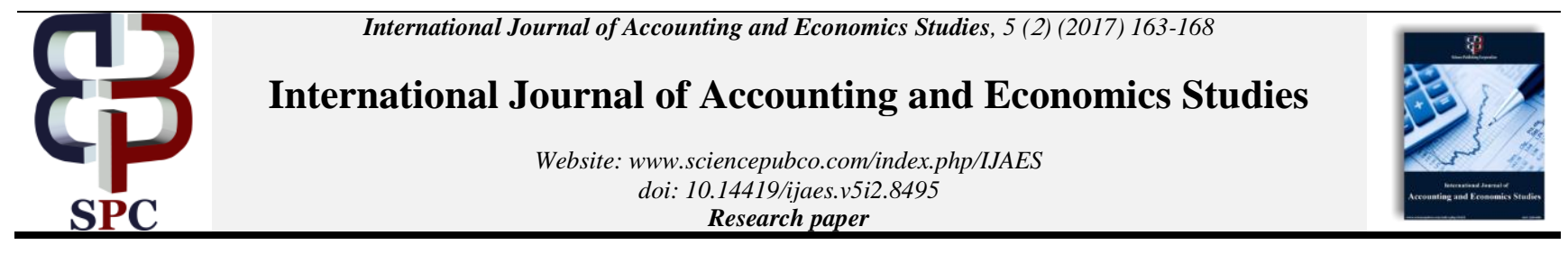

\title{
Informal sector in urban areas in Tanzania: some socio-demographic, economic and legal aspects
}

\author{
Mikidadi Muhanga * \\ Department of Development Studies, College of Social Sciences and Humanities, Sokoine University of Agriculture \\ *Corresponding author E-mail: mikidadi@suanet.ac.tz
}

\begin{abstract}
Urban settings worldwide are homes to the informal sector due to the sector's vast potentiality in terms of employment and income generation. Very little is found throughout the literature on the socio-demographic attributes of the informal sector in Tanzania despite its contribution to the economy. This paper empirically profiles informal sector in urban setting in Morogoro, Tanzania by analyzing socio-demographic, economic and legal aspects of the sector and those involved. Data was collected from 80 respondents using a questionnaire. Data analysis entailed descriptive statistics and cross tabulation. The results reveal dominance of men in the sector, low levels of education, young (19-26 years) and married people dominating, use of family labour, willing to operate businesses at times and locations convenient to customers. The study further shows that $55 \%$ of the activities obtained capital from owners' own sources and $82.5 \%$ of the activities operating were not licensed. The results further show that $50 \%$ of the activities /businesses surveyed were owned by families. Overall, the study asserts that the IS has a valuable contribution to the well being of the urban dwellers. The study recommends a need for addressing training needs and interventions by Local Government Authorities in the Informal Sector's operations for better performance and contribution to the livelihood of those involved but also to allow the Local Government Authorities earn income in form of taxes.
\end{abstract}

Keywords: Informal Sector; Informal Sector in Tanzania; Socio-Demographic; Urban Economy; Urban Areas in Tanzania.

\section{Introduction}

\subsection{Background information}

The Informal sector (IS) is identified differently depending on the context in which the term is applied (Harding \&Jenkins 1989; Portes et al., 1989; Renooy 1990; Muhanga \&Urassa 2014). The sector in some context is known as; 'Second Economy', 'Subterranean Economy', 'Hidden Economy', 'Underground Economy', 'Parallel Economy', 'Irregular economy', 'Shadow Economy', Black Economy, (ILO 1977; Gutmann 1977; Maliyamkono \& Bagachwa 1990; Muhanga \& Nombo 2010). There is evidence of having the sector so much linked to the urban centers as a result of the incapacity of the modern sector to absorb new entrants to the labour markets (Murillo \& Cartier 1988; Ranis and Stewart 1999; Munbodh 2003:4; Yuki 2007).

The IS has a long and well charted history in developing countries, as the concept was introduced into international usage in 1972 by the International Labour Organization (ILO) in its Kenya Mission Report (ILO 1972). There is an apparent renewed interest in the informal economy worldwide, for a number of reasons, the clearest include the fact that a large share of the global workforce and economy is informal and also the informal economy is growing in many contexts and appearing in new places and guises (Horn 2009; Muhanga \&Nombo 2010; Chen 2012; Vanek et al. 2012b). It is reported that the IS was born when growth in the organized economy contributed very little to absorbing the rapidly growing workforce in many developing countries (Martinusse 2006). However, this should not serve with the fact that IS exists only in the developing part of the world. Literature (IRS 1979; Tanzi 1982; Feige 1989; Harding \& Jenkins 1989; Hansson 1989; Isachsen \& Strom 1989) indicate that informal sector also exists in the developed world.

Various definitions are available for the concept (Kent \& Mushi 1995; Muhanga \& Nombo 2010). At the core, informality is looked at as a "way of doing things characterized by: (a) ease of entry; (b) reliance on indigenous resources; (c) family ownership; (d) small-scale operations; (e) labour intensive and adaptive technology; (e) skills acquired outside of the formal sector; (g) unregulated and competitive markets," simply all activities that largely operate outside the system of government benefit and regulation The IS was interpreted as individuals or groups of people engaged in legitimate enterprises (either subsistence or small scale), some of which may be regulated by the state, (i.e. cooperatives) but the vast majority are considered to be operating outside the legal framework of the state.

There is evidence that IS contributes significantly to the wellbeing of urban dwellers, but very little has been empirically documented with respect to the socio-demographic aspects of the informal sector in Tanzania. It is obvious though that demographic (population related) aspects are crucial parameters for economic development. Leaving alone the demographic aspects, Bagachwa \& Naho (1995) report an incomplete coverage as well as inaccurate estimates of the activities covered for the IS in the Tanzania's official National Accounts. This arises because many of the activities, especially those in the IS, are either misreported or underrecorded. The sector is, however, reported by O'Riordan (1996) as a rapidly expanding sector which by 1991 was believed to account for $22 \%$ of total employment in Tanzania, eighteen years later 
(2009) the sector was reported to stand at 48.1 percent in terms of employment in Tanzania (Osoro 2009). It is in the record that there is a notable increase in Labour Force in Tanzania Mainland (for Persons Aged 15 Years and Above) and a mismatch with available formal employment opportunities hence most of the entrants into the labour market rely on the IS (NBS 2014). Understanding the socio-economic and demographic aspects of the IS in the urban settings will contribute towards bridging the existing gap in terms of incomplete coverage as well as inaccurate estimates of the activities covered in the official accounts. It is obvious also understanding the socio-economic and demographic aspects of the IS in the urban settings will act as an ingredient in generating a consensus around the determinants of the informal sector among researchers. These paper profiles the IS in urban setting in Tanzania, it gives answers as to who is engaged in terms of the socio-demographic aspects, legal issues related to the activities and types of businesses involved.

\subsection{A Review of the is in Tanzania}

The IS has often been described as economically stagnant and unproductive, as encompassing the unskilled and the uneducated and politically inactive. For local governments who are responsible for the development and management of cities in developing countries, the informal sector has been looked upon as representing a dilemma. It presents both advantages and disadvantages that need to be taken into account when designing policies targeted at the sector (Srinivas 2009). The informal sector is regarded as an oxymoron - in one hand it is an unorganized 'nuisance' sector whose members, for example, do not pay any form of tax, on the other, it provides jobs and increases incomes of the most vulnerable groups in a city -the very low income group. Recently, nevertheless, research agendas have changed from focusing merely on the size of the IS to the dynamics at play within it (see ESRF 2010; TRA 2011).

It has strongly been noted that the IS has a significant job, income generation potential and stimulation of social economic growth in both urban and rural areas. According to the Integrated Labour Force Survey of 2006 (URT 2007) the IS was the second main employing sector after agriculture by employing 10.1 percent of the employed persons, followed by other private sectors with 8.6 percent, where agriculture employed 75.1 percent (TRA 2011). However, the social, economic and political reality of the IS translated to a complicated operational reality for business formalization and the tax administration (TRA 2011).

It is evident that the IS is growing as indicated by the 2006 Integrated Labour Force Survey (ILFS) that in 2006, 40 percent of all households in Tanzania Mainland were in IS activities as compared to 35 percent in 2001. In 2006, the urban IS employed about 66 percent of the people for whom the IS work is the main activity and only 16 percent of those for whom it is the secondary activity. In contrast, 34 percent of the people for whom IS work is a main activity are in rural areas and 84 percent for whom this work is a secondary activity. This suggests that the IS is a source of employment for majority poor Tanzanians (URT 2007).

Since 2000/2001 Tanzania Mainland has experienced a notable increase in Labour Force for Persons Aged 15 Years and Above from $15,490,730$ to $20,654,795$ in $2010 / 11$. According to NBS (2014) the total number of employees in the formal sector (FS) in Tanzania Mainland was $1,858,969$ in 2013; this is an increase of 308,951 employees from $1,550,018$ recorded in 2012. It is therefore clear that the IS has a large share of the workforce and contributes significantly to economic growth in Tanzania. TRA, (2011) and ESRF (2010) point out that the IS could be an important contribution to the Gross Domestic Product of Tanzania when taxed substantially.

Generally, scholars have changed their outlook, and regard IS as more dynamic, productive, and as a political challenger to the state, as well as an alleviator of the state. States in developing countries have also started to view the IS as more than just an underground, clandestine, surreptitious part of society, and regula- tions and policies have changed towards it (see TRA 2011, ESRF 2010; Chen 2012; Horn 2009; Vanek et al. 2012a). It is therefore, obvious that the IS in Tanzania is not a passive sector due to its socio-economic and political significance to the society. Hence understanding IS from the socio-demographic, economic and legal aspects is inevitable at the moment, much as IS cannot be separated from the society as it is a main source of employment hence income, but also linked so much to demography much as the population remains source of labour but also consumer of goods and services produced and offered by the sector. For IS to operate effectively obviously legal issues are to be taken on board now as it grows in size, as there are needs to regulate it..

\section{Theoretical debates on is}

\subsection{The dualist school}

The Dualist school sees the informal sector of the economy as comprising marginal activities-distinct from and not related to the formal sector - that provide income for the poor and a safety net in times of crisis (Hart 1973; ILO 1972; Sethuraman 1976; Tokman 1978).

The Dualists subscribe to the notion that informal units and activities have few (if any) linkages to the formal economy but, rather, operate as a distinct separate sector of the economy and that the informal workforce-assumed to be largely self-employedcomprise the less advantaged sector of a dualistic or segmented labour market. They pay relatively little attention to the links between informal enterprises and government regulations. But they recommend that governments should create more jobs and provide credit and business development services to informal operators, as well as basic infrastructure and social services to their families.

\subsection{The structuralist school}

The Structuralist school sees the informal economy as subordinated economic units (micro-enterprises) and workers that serve to reduce input and labour costs and, thereby, increase the competitiveness of large capitalist firms (Moser 1978; Castells \& Portes 1989).

The Structuralisms see the informal and formal economies as intrinsically linked. They see both informal enterprises and informal wage workers as subordinated in the interests of capitalist development, providing cheap goods and services. They argue that governments should address the unequal relationship between "big business" and subordinated producers and workers by regulating both commercial and employment relationships.

\subsection{The legalist school}

The Legalist school sees the informal sector as comprised of "plucky" micro-entrepreneurs who choose to operate informally in order to avoid the costs, time and effort of formal registration and who need property rights to convert their assets into legally recognized assets (de Soto 1989, 2000).

The Legalists focus on informal enterprises and the formal regulatory environment to the relative neglect of informal wage workers and the formal economy per se. But they acknowledge that formal firms what de Soto calls "mercantilist" interests - collude with government to set the bureaucratic "rules of the game" (de Soto 1989). They argue that governments should introduce simplified bureaucratic procedures to encourage informal enterprises to register and extend legal property rights for the assets held by informal operators in order to unleash their productive potential and convert their assets into real capital.

\subsection{The voluntarist school}

The Voluntarist school also focuses on informal entrepreneurs who deliberately seek to avoid regulations and taxation but, unlike 
the legalist school, does not blame the cumbersome registration procedures.

The Voluntarists pay relatively little attention to the economic linkages between informal enterprises and formal firms but subscribe to the notion that informal enterprises create unfair competition for formal enterprises because they avoid formal regulations, taxes, and other costs of production. They argue that informal enterprises should be brought under the formal regulatory environment in order to increase the tax base and reduce the unfair competition to formal businesses.

\section{Methodology}

This study was conducted in randomly selected wards in Morogoro Municipality; namely; Kingo, Mji Mkuu, Saba and Kiwanja cha Ndege. Morogoro municipality is among the fast-growing urban areas in Tanzania, being among fast growing urban areas is reported to accommodate a significant proportion of individuals engaging in IS (Muhanga \& Nombo 2010; Muhanga \& Urassa 2014 ). The wards selected are the ones forming the central part of Morogoro municipality where most of these IS activities are conducted, hence justifying the choice of the study area.

The data used in this study were from primary sources collected from individual household heads in the selected wards in Morogoro Municipality. The process of primary data collection involved the use of a checklist, questionnaire and personal interviews.

Pre-testing of the questionnaire was carried out before the main investigation. Pre-testing of the research instrument covered some few individuals at Mbuyuni area. The objectives of the Pre-testing of the research instrument were (i) to pre-test both the checklis and the questionnaire, (ii) to determine the approximate time that will be needed to complete the data collection work, (iii) to ascertain the availability of data for the objectives of the research and (iv) to determine the most efficient way of carrying out the main research.

The study population consisted of all households that are involved in the IS found in the selected wards. Information of the status of the informal activities, households that are involving themselves in IS were obtained from Ten Cell leaders and the WEOs. Sampling frame consisted of the four wards, and the sample consisted of 80 households involved in the informal activities. A multiple stages sampling technique was used in selecting households in each of the four wards. In the first stage strategic/purposive sampling was used to obtain households involved in IS. Sampling unit was a household and respondents were the household heads or representatives. Selected households were considered to be representatives of the households involved in IS in the selected wards. Data analysis was done using SPSS which involved calculation of descriptive statistics and cross tabs. Descriptive statistics such as frequencies, ratios and percentages were used to present some aspects assessed with respect to socio-economic and demographic aspects of the IS in selected wards in Morogoro Municipality Statistical Package for Social Science (SPSS) software was used in data analysis.

\section{Results and discussion}

\subsection{Socio and demographic characteristics of the re- spondents}

Socio and demographic characteristics of the respondents are found to be very important in social studies (Muhanga \&Malungo 2017; Kaale \&Muhanga, 2017). Information on three aspects of socio-demographic characteristics namely sex, marital status and education level of the respondents are presented in Table 1. These aspects provide the background for other findings.
Table 1:

\begin{tabular}{llll}
\hline Variable & \multicolumn{3}{c}{ Frequency Percentages } \\
\hline Sex & Female & 25 & 31.2 \\
Marital Status & Male & 55 & 68.8 \\
& Married & 48 & 60.0 \\
& Single & 19 & 23.8 \\
& Divorced/separated & 8 & 10.0 \\
Education Level & Widowed & 5 & 6.2 \\
& No formal edu. & 25 & 31.2 \\
& Primary education & 36 & 45.0 \\
& P.E +Other training & 11 & 13.8 \\
& Secondary education8 10.0 \\
\hline
\end{tabular}

\subsection{Sex and age of the respondents}

The sample of the respondents surveyed comprised of $68.8 \%$ men and $31.2 \%$ women as presented in Table 1 . The findings conform in a way with those by URT (1995) which reported an increase of women operators in the IS, but still declaring the dominance of men in the sector. The findings from the study revealed that females of the age group between 19-26 years are the one dominating the IS among the females, accounting for $11.25 \%$ of those operators in the IS (male and female), this age group (19-26 years) is forming $36.05 \%$ of the females involving themselves in the IS in the selected wards. This group is mainly made up of girls who have just completed schools and could not find way to formal employment. NBS (2014) reports a notable increase in Labour Force in Tanzania Mainland covering Persons Aged 15 Years and above and a mismatch with available formal employment opportunities hence mostly relying on the IS.

Table 2: Age of the Respondents in Percentage $(\mathrm{N}=80)$

\begin{tabular}{llllll}
\hline \multicolumn{5}{c}{ Age of the respondents } \\
\hline & $19-26$ & $27-34$ & $35-42$ & $43-49$ & $50 \geq$ \\
Male & 12.5 & 13.8 & 20 & 15 & 7.5 \\
Female & 11.25 & 6.2 & 7.5 & 2.5 & 3.75 \\
\hline
\end{tabular}

\subsection{Marital status}

The results in Table 1 further show that $60 \%$ of the respondents were married while $23.8 \%$ were single, $10 \%$ separated or divorced and $6.2 \%$ were widowed. These results are typical characteristics of many areas in Tanzania whereby $60 \%$ women and $50 \%$ men are married (NBS 2005). This indicates that involvement in the IS has been in a way influenced by the responsibilities individuals are shouldering in their community. Married people have more responsibilities for their families compared to those who are single. In this regard the IS is serving as a source of income. Studies are indicating that to most of the urban poor the IS has for a long time in the absence of formal employment opportunities been a way to rescue them (ILO 1972; The World Bank, 2009).

\subsection{Education level of the respondents}

Education is regarded as a major determinant factor towards formal employment in Tanzania. This study focused on this variable to assess whether those in the IS have the same level of education as those in the formal sector. The results in Table 1 indicates that $45.0 \%$ of the respondents had completed primary school, followed by $31.3 \%$ with no formal education, $13.8 \%$ with primary education plus other training and only $10 \%$ having secondary school education. The small percentage having secondary school education may be due to the fact that after attending primary education, which is compulsory for all, could not either afford or pass for higher education. Furthermore, one has to pass the primary school leavers exam to be eligible to join government run school. Whereas those failing could join private schools which are expensive and out of reach for the majority of poor households. Munbodh (2003) documented the relation between education level and involvement in IS. Formal employment to a larger extent at least requires secondary education in Tanzania (Mushi \& Kent 1995). 


\subsection{Types of businesses found in the selected wards}

Table 3 presents the findings with respect to the types of business found in the selected wards which are related to the IS. The study found that food vending accounted for $26.4 \%$, followed by carpentry (13.8\%), Tailoring (12.6\%), Welding (12.6\%), Laundry work (dhobi) $(9.2 \%)$, shoe shining $(9.2 \%)$, shoe making $(6.9 \%)$, selling of second hand clothing (mitumba) (4.6\%) and seat cover making accounting for $4.6 \%$.

Table 3: Types of Businesses Found in the Selected Wards $(\mathrm{N}=80)$

\begin{tabular}{lcc}
\hline Type of activity & Frequency & Percent \\
\hline Carpentry & 12 & 13.8 \\
Laundry i.e washing clothes (dhobi) & 8 & 9.2 \\
Food vending & 23 & 26.4 \\
Selling second hand clothing & 4 & 4.6 \\
Seat cover making & 4 & 4.6 \\
Shoe making & 6 & 6.9 \\
Shoe shining & 8 & 9.2 \\
Tailoring & 11 & 12.6 \\
Welding & 11 & 12.6 \\
Total & 80 & 100.0 \\
\hline
\end{tabular}

The types of businesses found in the selected wards have been significantly influenced by the location of the study area. The selected wards of Kingo, Kiwanja cha Ndege, Saba Saba and Mji Mkuu form the core urban part of the Morogoro Municipality. It has been a common phenomenon to find the businesses reported in Table 3 under the IS conducted in locations convenient to the customers, this is evident from the studies by Munbodh (2003) and McLaughlin (1990). The types of business found reflect the needs of the urban population in a way. It is obvious that many youth particularly single or generally people living alone normally would not prefer to cook hence buying form vendors. In addition same people and especially youth don not have time to wash their clothes or find it convenient to have them washed at a fee hence the expansion of the informal laundry services and others.

\subsection{Business location for the IS}

Business location is an important aspect that distinguishes formal sector from an informal one (McLaughlin, 1990). Respondents in this study were asked how they decided on premises for their businesses/activities. The study revealed that $68.8 \%$ of the respondents were willing to operate businesses at times and locations convenient to customers; and only $31.2 \%$ regarded it important to have their business in locations convenient to their businesses. It has been a common phenomenon to find the businesses under the IS conducted in locations convenient to the customers. The results support what has been reported by Munbodh (2003) and McLaughlin (1990).

\subsection{Business skills possessed}

Effective production in any activity depends on, inter alia, skillfulness of those who are involved in that particular activity. This study found it worthwhile to elicit information on the kind of formal business skills possessed by those involved in the IS in the selected wards in Morogoro Municipality. The study revealed that $75 \%$ of the respondents did not possess any business skills, while $25 \%$ had business skills. However the sector is boosted by experience, adoption and innovation of those involved in it.

\subsection{Source of labour}

Human resource is one of the most critical resources in any activity, as offices, machines and any other nonhuman resources cannot become productive except for the human efforts (labour). The findings from the study revealed that $57.5 \%$ of labour source was from the family members; whereas $23.7 \%$ accounted for own labour source and $18.8 \%$ of the activities had hired labourers. Other studies (McLaughlin 1990; O’Riordan 1991) have identified simi- lar trends with respect to the source of labour in the IS, whereas it has been a common phenomenon to have family labour (labour force from family members) contributing significantly for the labour used in the IS. The details are presented in Table 4

Table 4: Source of Labour Used in the IS $(\mathrm{N}=80)$

\begin{tabular}{lll}
\hline Labour Source & Frequency & Percent \\
\hline Employees & 15 & 18.8 \\
Family labour & 46 & 57.5 \\
Own & 19 & 23.7 \\
Total & 80 & 100.0 \\
\hline
\end{tabular}

\subsection{Source of capital for the business}

Opening up any business activity requires capital, this study took interest to investigate into the sources of capital for the IS activities. The study revealed that $55 \%$ of the IS activities were financed from own sources, whereas $33.8 \%$ obtained capital through assistance from a friend or a relative, $6.3 \%$ through loan(s) from friend(s), and 2.5\% through loan(s) from Micro-Finance Institutions. The results of this study conform to the findings made by O'Riordan (1996) which reports that the operators in the IS mainly obtain capital from their own sources to start their businesses. Table 5 presents the details.

Table 5: Source of Capital for Business/Activity in the IS (N=80)

\begin{tabular}{lll}
\hline Source of capital & Frequency & Percent \\
\hline A loan from MFI & 2 & 2.5 \\
A loan from a friend & 5 & 6.3 \\
Assistance from a friend or relative & 27 & 33.8 \\
Own sources & 46 & 57.5 \\
Total & 80 & 100.0 \\
\hline
\end{tabular}

\subsection{Legal status of business}

Among the cardinal legal requirements for opening up any business, is to have a business license. In the course of analyzing the characteristics of the IS activities in selected wards in Morogoro Municipality, the study investigated the legal status of such businesses, that is, aspects of licensing of the respective businesses. It was found that $82.5 \%$ of the businesses operating in the IS in the selected wards were not licensed and only $17.5 \%$ had licenses. These findings qualify the activities surveyed as being in the IS basing on the definitions provided by various scholars. These findings concur with those by ILO (1998), where ILO reports that most informal traders do not (or are unable to) comply with regulations concerning registration, licensing, tax payments, occupational safety, health, and working conditions. This inability is ascribed to a number of factors, including cumbersome bureaucracies, high costs, unreasonable demands, ambiguous regulations and negative state attitudes to workers in the informal economy. The World Bank (2009) also points out to the fact that the IS is unofficial business which is evading tax, avoiding labour regulations and other government or institutional regulations, with no registration of the business.

Business ownership

Business ownership was another aspect considered important by this study. The IS is considered as a subset of household enterprises or unincorporated enterprises owned by households. Table 5 presents the findings with respect to business ownership.

Table 6: Distribution of Activity/ Business Ownership (N=80)

\begin{tabular}{lll}
\hline Business ownership & Frequency & Percent \\
\hline Owned by my family & 40 & 50.0 \\
A different entrepreneur & 1 & 1.3 \\
Jointly owned & 1 & 1.3 \\
Individually owned & 38 & 47.5 \\
Total & 80 & 100.0 \\
\hline
\end{tabular}

The findings presented in Table 6 revealed that $50 \%$ of the activities /businesses surveyed were owned by families (this involved inherited properties and run by members of the family in an extended sense), $47.5 \%$ being owned by individuals (initiated by the 
current owners and being managed by them), joint ownership (by different individuals who do not have family ties) accounting for only $1.3 \%$ and $1.3 \%$ accounted for the activities owned by a different entrepreneur. Similarly, issues of ownership of businesses in the IS are reported by McLaughlin (1990) and Mushi and Kent (1995). Generally IS enterprises itself is dominated by sole proprietorship and the business management is embodied in one person.

\section{Conclusion}

It is definitely that the informal sector cannot be separated from the urban settings where the majority of urban dwellers find their livelihood much as the sector has a significant job, income generation potential and stimulation of social economic growth in both urban and rural areas, despite having that share but yet contributes marginally to tax revenue generation. The male members of the society are found to dominate the sector with a low level of education, young individuals also engaging so much in the sector and mostly married individuals. In terms of setting and characteristics, most of the business activities surveyed in this study relied on indigenous resources; owned by the family members; most businesses operated in a small scale; labour intensive; most of the operators acquired skills outside of the formal sector and the business activities were not registered. These observations qualify what is mostly described in literature related to IS. It is recommended that the LGAs and micro finance institutions work together to improve the conditions out of which the IS operated in Morogoro, for LGAs it is imperative to create policy responses to the sector which is becoming dominant in the urban areas in terms of being a mechanism of employment and income generation. Microfinance institutions also have a role to play towards creation of conducive and supportive environment to the IS by providing soft loans those involved.

\section{Acknowledgment}

I am indebted to all individuals who participated in a survey which provided data that led to this paper. Special thanks are due to the various officials in wards where this study was undertaken for giving permission to go around collecting data. Any errors or omissions are solely responsibility of the author.

\section{References}

[1] Bagachwa MSD \& Naho A (1995), Estimating the second economy in Tanzania, Elsevier Science Ltd.

[2] Castells M and A. Portes (1989), "World Underneath: The Origins, Dynamics, and Effects of the Informal Economy." In A. Portes, M Castells \& Lauren A. Benton, eds. The Informal Economy: Studies in Advanced and Less Advanced Developed Countries. Baltimore, MD, USA: John Hopkins University Press.

[3] Chen MA (2012), the Informal Economy: Definitions, Theories and Policies. Women in Informal Employment: Globalizing and Organizing (WIEGO) Working Papers Series. WIEGO Working Paper No 1 August 2012

[4] Coate E (1993), the introduction of total quality management at State University of Oregon. Higher Education 25(4): 303-320. https://doi.org/10.1007/BF01383856.

[5] De Soto H (1989), the Other Path: The Economic Answer to Terrorism. New York: HarperCollins.

[6] De Soto H (2000), The Mystery of Capital: Why Capitalism Triumphs in the West and Fails Everywhere Else. New York: Basic Books.

[7] ESRF (The Economic and Social Research Foundation) (2010), Informal Sector Taxation in Tanzania. TAKNET Policy Brief Series No. $012-2010$

[8] Feige EL (1989), the Underground Economies: Tax Evasion and Information Distortion (ed.), Cambridge University Press.

[9] Gutmann PM (1977), the Subterranean Economy, Financial Analysts Journal, Vol.34: 24-27. https://doi.org/10.2469/faj.v33.n6.26.

[10] Hansson I (1989), "the Underground Economy in Sweden", in Feige (eds.), the Underground Economy: Tax Evasion and Infor- mation Distortion, Cambridge University Press, pp. 219-37. https://doi.org/10.1017/CBO9780511571749.011.

[11] Harding P \& Jenkins R (1989), the Myth of the Hidden Economy: Towards a New Understanding of Informal Economic Activity, Open University Press, Milton Keynes, Philadelphia.

[12] Hart K (1973), Informal Income Opportunities and Urban Employment in Ghana, Journal of Modern African Studies, Vol. 11, No. 1. https://doi.org/10.1017/S0022278X00008089.

[13] Horn, ZE (2009), No Cushion to Fall Back On: The Global Economic Crisis and Informal Workers. Cambridge, MA, USA: WIE$\mathrm{GO}$ and Inclusive Cities.

[14] International Labour Office (ILO) (1972), Employment, Income and Equality: A Strategy for Increasing Productivity in Kenya. (A Report of an Inter-Agency Team Financed by the United Nations Development Programme and Organized by the International Labour Office), Geneva 600 pp.

[15] Internal Revenue Service (IRS), (1979), Estimates of Income Unreported on Individual Income Tax Returns, Washington DC: Government Printing Office.

[16] Isachsen AJ \& Strom S (1989), the Hidden Economy in Norway with Special Emphasis on the Hidden Labor Market", in Feige (eds.), the Underground Economy: Tax Evasion and Information Distortion, Cambridge University Press, pp. 251-67. https://doi.org/10.1017/CBO9780511571749.013.

[17] Kaale G \&Muhanga MI (2017), Sexual health knowledge among secondary school students in Morogoro, Tanzania: half full or full empty? International Journal of Health, Vol.5 (2), 120-125. https://doi.org/10.14419/ijh.v5i2.8190.

[18] Kent DW \& Mushi PSD (1995), the education and training of artisans for the Informal Sector in Tanzania - Education Research Paper No. $18,143 \mathrm{p}$.

[19] Lipsey MW \& Wilson DB (2000), Practical Meta -Analysis, Sage Publications, Thousand Oaks, California. 227pp.

[20] Maliyamkono TL and Bagachwa, M.S.D. (1990). The Second Economy in Tanzania. Eastern African Studies. ESAURP, Dsm. $197 \mathrm{pp}$.

[21] McLaughlin S (1990), Skill training in the IS: Analyzing success and limitations of support programs. In: The IS revisited (Edited by Turnham, D, Salomé, B \& Schwarz, A.), Development Center of the Organization for Economic Co-operation and Development (OECD), Paris. pp. 202-209.

[22] Moser CN (1978), Informal Sector or Petty Commodity Production: Dualism or Independence in Urban Development. World Development, Vol. 6. https://doi.org/10.1016/0305-750X(78)90062-1.

[23] Muhanga MI and Nombo CI (2010) Local Government policy responses to informal sector in Morogoro, Tanzania: seeing problems in an opportunity or seeing an opportunity in problems? African Affairs, Vol. 8, 133-156.

[24] Muhanga MI \&Urassa JK (2014), how informal is the Informal Sector? An analysis of the Setting and Characteristics of the Informal Sector in Morogoro, Tanzania. A paper presented at Mwenge Catholic University 1st Annual Conference, October 29TH - 30TH, 2014, At Moshi, Kilimanajro, Tanzania.

[25] Muhanga MI \& Malungo JRS (2017), Does Attitude Associate, Correlate, or Cause Behaviour? An Assessment of Attitude towards Health Behaviour under One Health Approach in Morogoro, Tanzania. International Journal of Advanced Research and Publications (IJARP). Volume 1 (3), 82-91.

[26] Munbodh S (2003), Mobile unit for the informal sector.[http://www.unevoc.unesco.org/../papers/MAR.Munbodh.infor mal.doc]. Accessed 7 August 2017.

[27] Murillo G \& Cartier W (1988), Urbanization, the informal sector and migration: issues for research and cooperation. Rev Can Etudes Dev., 9(1):7-17. https://doi.org/10.1080/02255189.1988.9670204.

[28] O'Riordan J (1996), The IS and the Alleviation of Poverty from a Gender Perspective in ESAURP Tanzania's Tomorrow, Tema Publishers Ltd, Dsm. 388 pp.

[29] Portes A, Castells M \& Benton LA (eds.) (1989), the Informal Economy: Studies in Advanced and Less Developed Countries, Baltimore, Johns Hopkins University Press.

[30] Ranis G \& Stewart F (1999), V-goods and the role of the urban informal sector in development, Economic Development and Cultural Change, 47 (2), 259-288. https://doi.org/10.1086/452401.

[31] Renooy PH (1990), the Informal Economy: Meaning, Measurement and Social Significance. Netherlands Geographical Studies, Amsterdam.

[32] Sethuraman SV (1976), the Urban Informal Sector: Concept, Measurement and Policy. International Labour Review, Vol. 114, No. 1. 
[33] Srinivas H (2009), the Informal Sector "Yes, but ..." Attitudes towards the IS. [http://www.gdrc.org/informal/index.html] site visited on 14.06.2009.

[34] Tanzi V (1982), the Underground Economy in the United States and Abroad, Toronto. Heath and Co. Lexington, Massachusetts, Toronto.

[35] The World Bank (2009). Concept of IS. Informal Labour Markets in Transition Economies. The World Bank Group, New York

[36] Tokman V (1978), an Exploration into the Nature of the InformalFormal Sector Relationship." World Development, Vol. 6, No. 9/10 https://doi.org/10.1016/0305-750X(78)90063-3.

[37] URT (2007), Analytical Report for Integrated Labour Force Survey (ILFS), 2006. National Bureau of Statistics, Ministry of Planning, Economy and Empowerment, Tanzania Gender Networking Programme (TGNP) and Ministry of Labour, Employment and Youth Development (MLEYD). Dar Es Salaam

[38] URT- TRA (2011), Review of Informal Sector for Taxation Purposes. TRA Headquarters, Dar Es Salaam.

[39] URT-NBS (2014), Formal Sector Employment and Earnings Survey. National Bureau of Statistics, Ministry of Finance. Dar es Salaam.

[40] Vanek J, Chen M \& Hussmanns R (2012a), Statistics on the Informal Economy: Definitions, Findings, and Challenges. Women in Informal Employment: Globalizing and Organizing (WIEGO) Working Paper No 2. Cambridge, MA, USA: Women in Informal Employment: Globalizing and Organizing (WIEGO).

[41] Vanek J, Chen M, Hussmanns R. Heintz J \& Carre F (2012b) Women and Men in the Informal Economy: A Statistical Picture Geneva: International Labour Organization and Women in Informal Employment: Globalizing and Organizing (WIEGO).

[42] Yuki K (2007). Urbanization, informal sector, and development. Journal of Development Economics, 84(1), 76-103. https://doi.org/10.1016/j.jdeveco.2006.09.004. 